\title{
Indoor air quality in Portugal: technical, institutional and policy challenges in the implementation of the directive on the energy performance of buildings (work in progress)
}

\author{
A. R. de Oliveira, A. T. Perez \& A. Morais \\ Instituto do Ambiente (Institute for the Environment), Portugal
}

\begin{abstract}
The implementation in 2006 of the Directive 2002/91/EC of the European Parliament and of the Council of 16 December 2002 on the energy performance of buildings in Portugal has brought new responsibilities to the Portuguese Institute for the Environment, namely the supervision of the Indoor Air Quality (IAQ) aspects in the Energy and IAQ National Certification in Buildings law. Following the transposition of the European Directive into Portuguese law, a Protocol was signed in July 2006, laying down the foundation for the establishment of qualified independent experts, in terms of minimum requirements and accreditation process.

Part of the role of the Institute for the Environment in this implementation process is to initiate, administer and participate in establishing an IAQ accreditation process to qualify a first tier of independent IAQ experts. These in turn will be responsible for future accreditation sessions. In preparation for this process, the Institute for the Environment has been initiating supervising and participating in the development of IAQ Certification and Management Plans, as well as in the IAQ accreditation courses that will take place in Portugal from October 2006 until April 2007.

This paper presents some aspects of the IAQ plans and procedures developed in Portugal for this effect. It sheds light on some of the technical, institutional, and policy challenges and highlights some of the constraints encountered so far. Special attention is given to the investment in the harmonization of existing IAQ knowledge, practices and procedures, and the effort needed to fill in some of the knowledge gaps observed.
\end{abstract}

Keywords: IAQ accreditation, IAQ Management Plans, IAQ Certification of Buildings, Portuguese IAQ policies. 


\section{Introduction}

The objective of this paper is to focus on the main technical, institutional and policy challenges in the implementation of the EPDB, rather than exploring the technical specifics of the IAQ policy. In fact, existing IAQ regulations in Portugal still lack technical amendments, as well as the rules that define the accreditation process of all specialists that will allow the full implementation of those regulations.

The implementation in 2006 of the Directive 2002/91/EC of the European Parliament and of the Council of 16 December 2002 on the Energy Performance of Buildings (EPBD) in Portugal has brought new responsibilities to the Portuguese Institute for the Environment. Although the EPBD focuses mainly on limiting outdoor carbon dioxide emissions through the promotion of energy efficiency, it also draws attention to the need to improve "indoor climatic conditions" in buildings.

It is the responsibility of the Institute for the Environment to supervise the implementation of the National System of Energy and Indoor Air Quality Certification of Buildings (Sistema Nacional de Certificação Energética e da Qualidade do Ar Interior em Edifícios, "SCE" in short), which transposes the EPBD in Portugal, in what concerns IAQ requirements in buildings.

In the national legislative context, the National System of Energy and Indoor Air Quality Certification of Buildings constitutes a tool to implement energy efficiency under the Energy National Strategy (Estratégia Nacional para a Energia) as well as under the National Program for Climate Change (PNAC Programa Nacional para as Alterações Climáticas) in Portugal.

Following the transposition of the European Directive into Portuguese law, a series of national regulations (Decreto-Lei) were published in April 2006 [1-3] some of which repealed previous energy related regulations that were not always wholly implemented or fully adequate. Protocols were signed in 2006 between the various entities involved in the certification process to define procedures and minimum requirements for the accreditation of "qualified experts" (independent energy and IAQ experts) and heating ventilation and air conditioning (HVAC) installation, maintenance, and "IAQ-certified technicians".

Part of the role of the Institute for the Environment in this implementation process is to initiate, administer and participate in the accreditation of the firsttier qualified independent IAQ experts. These experts will in turn be responsible for future accreditation campaigns. In preparation for this process, the Institute for the Environment has been supervising and participating in the development of IAQ Certification and Management Plans, as well as in the SCE accreditation courses that is taking place in Portugal from October 2006 until April 2007.

\section{IAQ regulations in Portugal}

Prior to the introduction of the new indoor air quality requirements in the context of the energy and IAQ certification process, indoor air quality regulations in Portugal were limited to occupational health and safety guidelines. 
These guidelines focused primarily on the quality of industrial microenvironments including their temperature, relative humidity, ventilation rates, and on toxic industrial chemicals such as benzene and formaldehyde.

In 2002, the Ministry of Environment drafted a legislative initiative that aimed the implementation of an indoor air quality law in non-industrial buildings, but it remained dormant. As a response to the increasing concern of exposure to air pollutants in indoor non-industrial environments this initiative was integrated in the existing air quality and energy efficiency regulations in the context of the transposition of the EPBD to Portuguese law in 2006. As a result, a comprehensive IAQ certification program will be implemented along with the energy efficiency certification of buildings in Portugal.

Table 1: IAQ Regulations.

\begin{tabular}{|c|c|}
\hline Regulation & Contents / IAQ Requirements \\
\hline $\begin{array}{l}\text { Decreto-Lei } 78 / 2006, \text { April } 4^{\text {th }} \\
\text { National System of Energy and IAQ } \\
\text { Certification in Buildings (SCE) }\end{array}$ & $\begin{array}{l}\text { Sets the main rules of the certification } \\
\text { national system. Refers to the need to } \\
\text { maintain a good IAQ while pursuing } \\
\text { energy efficiency goals. }\end{array}$ \\
\hline $\begin{array}{l}\text { Decreto-Lei } 79 / 2006 \text {, April } 4^{\text {th }} \\
\text { Regulation of the Energy Heating and } \\
\text { Cooling Systems in Buildings } \\
\text { (RSECE) }\end{array}$ & $\begin{array}{l}\text { Regulates the SCE in buildings with } \\
\text { HVAC systems. Applies mostly to } \\
\text { large new and existing service } \\
\text { buildings. Includes IAQ requirements } \\
\text { in terms of air renovation rates (new } \\
\text { buildings) and maximum } \\
\text { concentration of air pollutants (PM10, } \\
\mathrm{CO} 2, \mathrm{CO}, \mathrm{O} \text {, formaldehyde, TVOC), } \\
\text { bacteria (including Legionella), fungus } \\
\text { and radon (existing buildings). Also } \\
\text { includes IAQ recommendations in the } \\
\text { design and location of buildings. }\end{array}$ \\
\hline $\begin{array}{l}\text { Decreto-Lei 80/2006, April } 4^{\text {th }} \\
\text { Regulation of the Thermal } \\
\text { Characteristics of Buildings (RCCTE) }\end{array}$ & $\begin{array}{l}\text { Regulates the SCE in buildings } \\
\text { without HVAC systems. Applies } \\
\text { mostly to small new and existing } \\
\text { service and residential buildings. IAQ } \\
\text { requirements relate to temperature and } \\
\text { humidity levels. }\end{array}$ \\
\hline SCE Protocol, July 21, 2006 & $\begin{array}{l}\text { Sets the foundation for the creation of } \\
\text { qualified independent experts, in terms } \\
\text { of minimum requirements and } \\
\text { accreditation process. }\end{array}$ \\
\hline RSECE Protocol, November 2006 & $\begin{array}{l}\text { Sets the foundation for the creation of } \\
\text { HVAC installation and maintenance, } \\
\text { and IAQ certified technicians. }\end{array}$ \\
\hline
\end{tabular}


Table 1 lists the Portuguese regulations and protocols created so far under the EPBD, and summarizes some of the regulatory and procedure requirements as they pertain to indoor air quality.

\section{IAQ audits, plans and procedures}

IAQ audits will take place at three different stages during the construction and commissioning of buildings; (a) the building permit, (b) the use/occupancy permit, and (c) during the life of the building, as follows.

(a) Verification of IAQ requirements and issues in the project design: air change rates (taking into account air circulation patterns and ventilation efficiency), sources of pollution (materials, equipments and type of occupancy), and the location for air intakes.

(b) Verification of ventilation conditions, presence of unplanned pollution sources, and the presence of a comprehensive and adequate "IAQ Maintenance Plan".

(c) IAQ audit during the building's regular occupancy period, which includes the measurement of indoor air pollutants. The frequency of IAQ's audits during building's occupancy depends on the category of a building and its use.

An IAQ Maintenance Plan will be required for each building under the Regulation of the Energy Heating and Cooling Systems in Buildings, and will be prepared under the responsibility of the IAQ-certified technician. It will include information about the activities carried out in the building, equipments and materials used and the preventative maintenance procedures applied to guarantee a good indoor air quality, among others.

The qualified expert who conducts the audit will make the outcome of each IAQ audit available in an IAQ Report. If all IAQ requirements are met, the qualified expert, through ADENE, issues an IAQ Certificate. In case of nonconformity to IAQ requirements at the time of the audit, the qualified expert should include in the IAQ report relevant information and possible remediation actions that can be used in the development of the Corrective Measures Plan.

The owner of the building will be responsible for submitting the Corrective Measures Plan to the Institute for the Environment, pointing out improvements that will lead to compliance with good indoor air quality requirements. Following the implementation of the remediation actions mentioned in this plan, a follow up audit will be carried out to verify the conditions to either recommend further corrective measures or certify full IAQ compliance.

The IAQ certification in residential buildings to which the Regulation of the Energy Heating and Cooling Systems in Buildings applies is valid for ten years. Non-residential buildings such as office buildings will require IAQ certification every 2, 3 or 6 years, depending on their use.

All information pertaining to the National System of Energy and Indoor Air Quality Certification in Buildings process, including registration of Qualified 
Experts and registration of energy and IAQ audits, IAQ Maintenance Plans, IAQ Corrective Measures Plans, will be centralized in a database at the Energy Agency (ADENE) in Lisbon.

\section{IAQ in Portugal: challenges, constraints and opportunities}

The main challenges associated with the consideration of IAQ requirements in the current law and, specifically, in the context of energy efficiency objectives, include technical, institutional and organizational issues.

The first step in the certification process consisted in the definition of the minimum qualifications required from and training needs of first-tier professionals that will become the national IAQ experts, the future and the main agents of the energy efficiency and IAQ certification process. The Institute for the Environment worked closely with existing IAQ professionals from national institutions and academia including IAQ researchers, microbiologists, and chemists and have consulted with members of relevant professional associations such as engineers and architects as well as related agencies to support the overall objectives of implementing an IAQ law in Portugal.

Air quality professionals have been working together with the support and supervision of the Institute for the Environment towards the development of IAQ procedures, management and plans including sampling methods and other aspects related to the IAQ certification process.

A considerable effort has been employed to link the different parties involved in the IAQ certification process. Each party brought its own view with different levels of expertise. Most of the parties involved have had an active role in the development of the National System of Energy and Indoor Air Quality Certification in Buildings with diverse responsibilities in the certification process. Table 2 lists the main parties involved in the process with respective roles.

Policy challenges related to IAQ are partly due to the lack of awareness by the public, and technical and policy agents, of the role of indoor air quality in public health and, consequently, in the human capital and its productivity. Given this challenge and the close and often conflicting energy efficiency and IAQ objectives, the Institute for the Environment has its own challenge. On the one hand, it needs to bring together the existing expertise in the areas of indoor air quality and public health and, on the other hand, it needs to integrate indoor air quality objectives and resources in the existing and partly implemented energy efficiency policies and resources so that both objectives can be simultaneously and seamlessly attained.

Another aspect worth mentioning is that contrary to what happens in regard to energy efficiency policies and related actions, indoor air quality issues have not been present in previous energy policies and regulations, nor has the Institute for the Environment had any previous regulatory responsibilities in indoor air quality. The past experiences of the Institute for the Environment in IAQ has been limited to air sampling and analysis provided by its laboratory in cases of indoor air quality investigations, as well as expert services in court cases. 
Currently, most IAQ sampling and analysis in Portugal is being conducted by public laboratories, universities and some private sector companies.

Table 2: $\quad$ Main IAQ certification parties and their roles.

\begin{tabular}{|c|c|}
\hline Entity & Role \\
\hline Institute for the Environment (IA) & $\begin{array}{l}\text { SCE-IAQ Supervision. Certification } \\
\text { of Qualified Expert Instructors. } \\
\text { Definition of minimum requirements } \\
\text { for Qualified Experts. Accreditation of } \\
\text { IAQ certified technicians. }\end{array}$ \\
\hline $\begin{array}{c}\text { Energy and Geology Directorate- } \\
\text { General (DGGE) }\end{array}$ & $\begin{array}{l}\text { SCE-Energy Supervision and Judicial } \\
\text { enforcement (fines). Certification of } \\
\text { Qualified Expert Instructor. Definition } \\
\text { of minimum requirements for } \\
\text { Qualified Experts. }\end{array}$ \\
\hline $\begin{array}{c}\text { Inspectorate-General for the } \\
\text { Environment and Spatial Planning } \\
\text { (IGAOT) }\end{array}$ & $\begin{array}{l}\text { SCE - IAQ Judicial enforcement } \\
\text { (fines) }\end{array}$ \\
\hline Energy Agency (ADENE) & SCE Management and Inspection \\
\hline $\begin{array}{c}\text { Professional Engineers Association } \\
\text { (OE), National Association of } \\
\text { Technical Engineers (ANET), } \\
\text { Professional Architects Association } \\
\text { (OA) }\end{array}$ & $\begin{array}{l}\text { Accreditation of candidates to } \\
\text { Qualified Experts, curricula approval, } \\
\text { etc. Definition of minimum } \\
\text { requirements for Qualified Experts. }\end{array}$ \\
\hline $\begin{array}{c}\text { Public Works and Transportation High } \\
\text { Council (CSOPT) }\end{array}$ & $\begin{array}{l}\text { Definition of minimum requirements } \\
\text { for Qualified Experts. }\end{array}$ \\
\hline $\begin{array}{c}\text { Professional Instruction Center for } \\
\text { Thermal and Energy Industry } \\
\text { (APIEF), HVAC Industry Portuguese } \\
\text { Association (APIRAC), HVAC } \\
\text { Engineers Portuguese Association } \\
\text { (EFRIARC) }\end{array}$ & $\begin{array}{l}\text { Accreditation of IAQ certified } \\
\text { technicians. }\end{array}$ \\
\hline
\end{tabular}

Ongoing IAQ courses aiming the accreditation of lecturers who will start their own courses to certify the first-tier qualified IAQ experts required an intense harmonization effort. The Institute for the Environment coordinated harmonization workshops that brought together all those responsible for those courses, and that allowed an unprecedented exchange of technical and scientific materials as well as a constructive discussion over the interpretation of the law with respect to new procedures and methodologies.

IAQ courses have focused on various topics, including: the regulatory process and agents; indoor air pollution physical, chemical and microbiologic characterization; indoor air pollution sources and health effects; preventive and corrective IAQ measures with focus on the HVAC systems; IAQ sampling, measurement and analysis; IAQ audits, reporting and case study. 


\section{Work in progress}

At the time of the writing of this draft paper (December 2006), the first Courses for Qualified Expert Lecturers (RSECE IAQ Module) have started, and it is expected that the IAQ Certification Module will take place in the first trimester of 2007. In addition to the role of the Institute for the Environment in coordination of the harmonization workshops for RSECE IAQ Module, and participation in the harmonization workshops for the IAQ Certification Module, technicians of the Institute are also providing lecturing services in both modules.

The Institute of the Environment is currently coordinating and supervising a team of IAQ professionals, in the preparation of Amendments (Portarias) to the national laws with respect to indoor air quality issues. These amendments will initially focus on the definition of sampling procedures, and the revision of the maximum allowed concentrations of indoor air pollutants, bacteria, and fungus.

The Institute of the Environment also provides technical support to the Energy Agency (ADENE) in all matters related to IAQ issues and procedures, and works alongside with IAQ professionals towards the full and up-to-date implementation of IAQ requirements in the national law.

\section{Lessons learned}

The work performed so far to attain IAQ requirements under the current certification regulations has been based on two main features: joint efforts and a multidisciplinary approach. The indoor air quality field is highly fragmented. It can only be put to practice if the various parties join their experiences towards a common goal. Likewise, IAQ polices have to be integrated into existing energy policies in order to minimize the gap between opposite goals in a cost-effective manner.

There is a need for a considerable increase in the exchange of expertise and information as they pertain to IAQ monitoring, auditing, and policy implementation procedures. This information exchange is needed to maximize the benefits of past, present and future efforts to protect public health in the environments where we spend most of our time, in home and at work.

It is also essential the safeguarding of a continuous effort that will integrate new findings about IAQ (sources of indoor pollution, materials with lower emissions, new ventilation \& HVAC technologies, etc), better information to the public about the relationship between IAQ and public health, and procedures that guarantee the full achievement of IAQ policy objectives.

We can only hope that the transposition of the EPBD into national laws in Europe will contribute to that intention.

\section{Acknowledgements}

The authors would like to thank all those involved in the joint effort to implement IAQ requirements in Portugal, in the context of the transposition of 
the EPBD. The authors are deeply thankful to Soheil Rastan and Pedro Restrepo for their contribution and encouragement.

\section{References}

[1] Decreto Lei 78/2006 de 4 de Abril, Sistema Nacional de Certificação Energética e da Qualidade do Ar Interior (SCE)

[2] Decreto Lei 79/2006 de 4 de Abril, Regulamento dos Sistemas Energéticos de Climatização em Edifícios (RSECE)

[3] Decreto Lei 80/2006 de 4 de Abril, Regulamento das Características de Comportamento Térmico dos Edifícios (RCCTE) 